\title{
Exploring Persistence Factors Of Students in Agricultural Science
}

\author{
Abdullah Mat Rashid \\ Irra Zahira Ishan \\ Nurul Farhana Mohamed
}

Universiti Putra Malaysia

DOI: https://doi.org/10.36941/jesr-2020-0o62

\begin{abstract}
The authors employed a qualitative case study design to explore factors of persistence in agricultural science program. Specifically focused on factors that influence participants continue in enroll the agricultural program in tertiary education since previously studied a subject or several subjects related to agriculture in secondary school. All participants had taken agricultural programs in tertiary education and previously had studied subject that related to agriculture during secondary school. Findings show that support from close individual, school environment, exposure to agriculture and personal factor were factors influencing the persistence of students in agriculture. The authors address implications for increasing student's persistence in agricultural science program.
\end{abstract}

Keywords: Agriculture education; perseverance; agriculture science student; case study; qualitative research; technical and vocational education and training (TVET)

\section{Introduction}

Variety of agricultural sector requires knowledgeable and skills workforce to sustainably produce enough to meet increasingly demands. Students in agriculture are expected to be the next generation of scientist, irrigation engineer, veterinarian, producers etc, yet most increasingly disinterested continuing in agricultural programs (Bennel, 2010). Hence, affecting their persistence in agriculture field. This scenario can give a serious implication for the future of global agriculture production with the growing disinterest in agricultural sectors as well related careers. Therefore, in order to provide a skilled, educated and competent worker with a strong agricultural background, efforts should be made starting at the school level and higher levels of education to strengthen student persistence in agriculture.

However, in Malaysia, report shows that the percentage of student pursuing science and technical stream including the field of Agriculture Science at the secondary level is lagging compared to art stream. The percentage has not only decreased dramatically over the years, reaching fifty percent decline of the student enrollment in science and technical stream. There are several studies found that the lack of student persistence in agriculture is due to strong perception that agriculture study is perceive as not important area of study, suitable for elderly or people lives in rural areas. This also among the reasons many young generation migrate from agricultural live hoods and rural 
area to urban area that they assumed offers them with many other work options.

\section{Literature Review}

A variety of factors influence students' persistence to study agricultural science. Among the factors identified were teachers (Ortega-Dela Cruz, 2015), social support from specific individuals such as parents (Powell, 2019) and friends (Wildman \& Torres, 2001), support from school environment such as institutional fit (Elder, 2020), quality of teaching and learning instruction (Ortega-Dela Cruz, 2015), variety of materials used in teaching, exposure to agriculture such as farming background and high school agriculture courses (Barkley \& Parrish, 2005), student's career preferences (Beggs, Bantham \& Taylor, 2008) as well as students' interest (Esters \& Bowen, 2005).

Most students attracted to agriculture science subjects because of the different teaching approaches that involve hands on and outdoor activities (Gary, Stacy \& Layle, 1999). Generation Z considered parents as the most influential individual of students' persistence in agriculture science, often followed by high school or college friends (Seemiller \& Grace, 2016). A study conducted by Swan and De Lay (2014) found parents and guardians more often have a significant impact on a student's choice in choosing the agriculture field.

The source of persistence related to exposure in the agriculture field includes prior experiences, other agriculture experiences and being associated with relatives who are involved in agriculture (Klein \& Washburn, 2012). The result from a study by Foreman, Retallick and Smalley (2018) found that students with existing experience in agriculture and grow up on a farm or rural area tend to persist in agriculture field. Career preferences also impact student's persistence in agriculture. Such preferences include the nature of the work for instance the opportunity to work in fields such as in the field's horticulture and livestock (Ortega-Dela Cruz, 2015), offering career stability (Baker, Chiarell \& Irani, 2013) and high-income generation (Pritchard, Fudge, Crawford \& Jackson, 2018). Other than that, students' interests often match the persistence with the field of agriculture (Seemiller \& Grace, 2016). However, despite all those opportunities in the agriculture field, students have negative perceptions towards the career path in agriculture (Garwe, 2015) due to lack of information in the agriculture field. Therefore, purpose of this study is to explore the factors influencing the persistence of students in agriculture science.

Agricultural students play an active role in agriculture development contributing to the nation output. They are expected to become the next generation of farmers, yet most increasingly disinterested continuing in agriculture. Hence, affecting their persistence in agriculture filed. This scenario can give a serious implication for the future of global agriculture production with the growing disinterest in agriculture and agriculture related careers. The global agricultural production sector required skilled labor and knowledgeable workforce in the field of agriculture to sustainably produce enough to meet rising global demands. Therefore, in order to provide a skilled, educated and competent worker with a strong agricultural background, efforts should be made starting at the school level and higher levels of education to strengthen student persistence in agriculture.

Nyoni (2015) founds that younger generation attract to pursue with white collar jobs instead of farming and other agriculture based careers due to the belief that farming is a mentally and physically challenging job. Meanwhile, Ogbeide, Ele and Ikheloa (2015) found that most people perceived agriculture related to hard work due to its low social status, harsh on the physical and lower rewards. This among factors contributes to lower attention among younger generation toward involving in field of agriculture science. Other factors that influence students' persistence to pursuing study agricultural science included teachers, variety of materials used in teaching and quality of teaching (Ortega-Dela Cruz, 2015), social support from specific individuals such as parents (Powell 2019) and friends (Wildman\& Torres, 2001), support from school environment such as institutional fit (Elder, 2020), exposure to agriculture such as farming background and high school agriculture courses (Barkley \& Parrish, 2005), student's career preferences (Beggs, Bantham \& Taylor, 2008) as well as students' interest (Esters \& Bowen, 2005). 
Gary, Stacy and Layle (1999) found that most students attracted to agriculture science subjects because of the different teaching approaches that involve hands on and outdoor activities. Meanwhile, a study Swan and De Lay (2014) suggested that parent more likely to have significant impact on a student's choice in choosing the agriculture field. The source of persistence related to exposure in the agriculture field includes prior experiences, other agriculture experiences and being associated with relatives who are involved in agriculture (Klein \& Washburn, 2012). The result from a study by Foreman, Smalley, and Retallick (2018) stated that students with existing experience in agriculture and grow up on a farm or rural areas tend to persist in agriculture field. Career preferences also impact student's persistence in agriculture. Such preferences include the nature of the work for instance the opportunity to work in fields such as in the field's horticulture and livestock (Ortega-Dela Cruz, 2015), offering career stability (Baker, Chiarelli \& Irani, 2013) and high-income generation (Pritchard, Fudge, Crawford \& Jackson, 2018). Despite lots of opportunities in agriculture sectors, students still show less interest towards career path in agricultural. Therefore, this study is to explore the factors influencing the persistence of students in agriculture science.

\section{Method}

A case study is adopted as a design since it permits an understanding of experiences across many cases (Creswell, 2018). In this study, participants involved had taken courses in agriculture science and previously studied a subject that related to agriculture in secondary school and tertiary education. The researcher makes an initial contact by phone explains the purpose of the study to each participant and their willingness to participate. Then, a formal request letter was sent to participants prior to set up for date, time and location to meet with them.

In this study, the researcher conducted face to face interviews with three participants following an interview protocol. The interview protocol included questions about the participant's background and early education, a related experience in agriculture science including subject, program in school, university, career and future plans. During the interviews session, clarifying and probing questions emerged as a natural progression of the interview. Researcher did a member-check to ensure the validity of the data. Each interview was tape-recorded with the consent of the informants, varied in length, and no two interviews were alike. During analysis, researcher conducted data triangulation to identify recurring patterns. The developments of the themes begin by naming initial codes. Then, the expended codes founded followed by categorized the final codes.

\section{Findings}

\subsection{Background of Participant}

A total of three participants were involved in the process of data collection. All participants in this study have taken courses in agriculture science or had previously studied a subject that related to agriculture in secondary school and higher education. Overall, all participants are women with ages range from 23-25 years old.

The major themes that arose from this study are: (1) Support from close individual (2) School Environment (3) Exposure to agriculture and (4) Personal factor. Within four of the major themes, sub-themes emerged as well.

\subsection{Support from close individual}

Participants agreed that support from close individual likes parents, extended families and teacher influence their persistence in agriculture science. Most participants acknowledge that parents play a significant role in the course selection of their children as the following statements illustrate from participant 1: 
"Participant 1: I have good support from my family especially from my parents"

Similarly, participant 2 and participant 3 asserted that their persistence in agriculture science was due to their parents' supports.

"Participant 2: My parents really encouraged me because..... they want to prove that I can thrive in this field. They want to change the perception of my relatives and the community that agriculture is a second class area. Hence, I got the urge and the perseverance to further in the agriculture field"

"Participant 3: When I bring up the issues that I have an interest in agriculture field..... my parents encourage me and told me to do whatever I think I will enjoy doing. The support from my parents enables me to be in this field"

Other participant mentioned that her extended families precisely her auntie also influence their persistence in agriculture science:

"Participant 1: My auntie also works at an estate as a personal assistant to an agriculture director. So, she does support me."

Furthermore, most participants agreed that their persistence in agriculture science was also due to the support from their teachers. For instance, participant 1 mentioned that she was exposed to agriculture science since primary school by a teacher in her school club.

"Participant 1: In primary school, students need to register to a school club for a co-curricular activity.... So, there this is one club, Herbal Club facilitated by Teacher Abdul Rahman. He was really nice. He gave me a lot of information, shares his experiences and informed me things that I could do. I get exposed to agriculture science by joining the Herbal Club."

Teacher approachability is important to the success of the student because when they feel comfortable, students are more likely to ask question thus make an active learning environment in the classroom. On the other hand, other participants stressed that school counselor and subject teacher were influenced them to retain in agriculture science. Most participants said that school counselor did encourage them as following statements illustrate:

"Participant 1: My school counselor did share about scope and course in agriculture, foundation school or university that offer agriculture program and guideline to apply these programs"

"Participant 2: Whereas, the encouragement itself, I didn't deny came from my high school counselor. He strongly encouraged us to enroll the Agricultural Science Foundation because we either received an invitation or received a pamphlet from the Agricultural Science Foundation about this degree."

Moreover, participant 3 noted that, student easily get influence by agriculture teacher.

"Participant 3: When we learned about the ruminant digestive system my classroom teacher, Teacher Alwi bought a chicken and demonstrated for us. He did a demonstration on fertigation and hydroponic system. The way he teaches us spark our interest to learn more about agriculture"

However, when participants were asked whether other people such as close friends give their negative views on student retention in agriculture science, participant responded:

"Participant 1: I have friends who are, you know, wondering the reason why I choose foundation in agriculture science instead of furthering my study in other foundation courses or matriculation colleges. And I have noticed that"

Similarly, participant 2 shared that her friends discouraged her to have persistence in agriculture science. 
"Participant 2: When I bring up the issues of my interest in the agriculture field among my friends, they will ask me, if I was thinking correctly? Whenever I mentioned agriculture field they react negatively."

One participant mentioned that her relatives did discouraged her by saying that agriculture field does not suit with her:

"Participant 1: Agriculture science is a difficult field and meant for men. If you choose this program, you are going into men field".

\title{
4.3 School environment
}

In terms of the school environment, the theme was divided into the following sub-themes that are teaching and learning activities, infrastructure and facilities. Most participants mentioned that the activities provided in the secondary school were interesting. The following are the responses given by the participants to activities conducted in high school:

\begin{abstract}
"Participant 1: We do sell our agriculture products especially on Canteen Day where parents and outsiders are welcome to our school."

"Participant 2: My schools encourage student activities during our practical session where we are encouraged to run agricultural activities ... for example raising chickens, growing vegetables and selling the agriculture product produce - our crops or our pets to other teachers during the bazaars. At the same time, we were also taught on how to handle the farm and to be creative with group work assignments. We successfully make a presentations in the classroom on how can we innovate existing agriculture"
\end{abstract}

Similarly, another participant who did active hands on activity shared her experience in the classroom activity. She has this to say:

"Participant 3: I love practical based and hands on activities. I had the experience of growing vegetables, selling agriculture products and caring for quail through my agriculture class"

"Participant 1: We also gain knowledge and experience through school trip like visiting a farm nursery conducted by the agriculture teacher"

Meanwhile, other participants saw student retention in agriculture science due to infrastructure and facilities provided by school management:

"Participant 3: My school provides two huge gardens for agricultural science students for their practical class"

"Participant 2: There are specific areas for agriculture science students and classes for students with learning difficulties where they are more likely to be exposed to hand-on activity such as raising chicken, catfish and growing vegetables. We learned in a theory class and we practice it through the activities outside of classroom"

\subsection{Exposure to agriculture}

Participants indicated that the role of society especially farming background and growing up environment affected the retention of students in agriculture science. Most of the participants believed that, farming background often impacts the selection of students to continue their studies. They are either supported or not and it could become a key obstacle if they are not supported. One participant explained that residential area also influences student persistence in agriculture science:

"Participant 2: Some people believed that agricultural science is a field for lower class family, I think it depends on socio economy of the family and where they live. I live in a community where the majority is farmers who run agriculture, so I believe that agriculture is not only for lower or middle class family. If 
we were to ask young people from a more professional background, living in the city, their answer would be negative in my opinion"

However, others expressed that farming background especially family background does influence them:

"Participant 1: My late grandparent is a farmer. My mother was born at Sungai Nibung, Kuala Selangor which is the area of paddy field. She was born and raised there. The same goes for my father, his hometown also planting paddy. So, agriculture backgrounds exist in my family"

"Participant 3: My father owns an oil palm farm and he takes care of animals like goats. I use to play there and climb the trees. Whereas, when I go back to my hometown I used to play at the paddy fields, catching fish and playing kite. So, from a young age I was familiar with the agricultural environment".

This is in line with another participant who advocated that her persistence in agriculture science was due to her family background.

"Participant 2: My parents were farmers, where they did their own agricultural work"

When participant were asked about others factor in social themes, informants expressed that growing up environment may influence them as the following statements illustrate:

"Participant 1: I was born at United Plantation Berhad, an estate area. My dad worked as a fruit picker and as I grew up he becomes farm contractor. He does manage the farm and harvests the fruit. My mother really liked to plant flowers and fruit trees. Sometimes I will help her watering the plants. Hence, the environment makes me used to agriculture environment"

"Participant 2: Well, from a young age I was exposed to agricultural activities like, my father asked me to go to the farm, how to plant trees, for example vegetable trees or else pruning the tree and doing fruit harvest. So, I feel like seeing agricultural products, the plants around me, it gives a wonderful picture of agricultural science"

"Participant 3: I grow up in the oil palm area, near to Sungai Besar, Kuala Selangor. Before I reach to my home, there is a huge paddy field before entering the palm oil area. Indeed, my grow up environment made me really close to paddy field and oil palm area".

\subsection{Personal factor}

In terms of personal factor, the theme was divided into the following sub-themes that are interest and own target. Most of the participants identified interest as one of the main factors that influence students to pursue their studies in agricultural science. Irrespective of the interest, the student's decision to continue his/her studies in agriculture is low. Participants have repeatedly stated that it was because of their deep interest in agriculture that they chose agriculture and made it their first choice to pursue in higher education. Among the statements given by participant were:

"Participant 1: I don't want to register in science class, because I don't want to study biology. It is a tough subject. I have more interest in agriculture science course”

"Participant 2: I found that agriculture is exciting field to explore. Thankfully I was offered to foundation school of Agriculture Science at UPM and I am very thankful to have that offer. Currently, I am pursuing Bachelor studies in Agricultural Science too. Agricultural Science Bachelor is the first of my five lists program to choose in university"

"Participant 3: Every evening my friends and I went to the garden to do practical activities like sowing seeds, cutting grass, pruning and harvesting crops. I enjoy those agriculture activities"

Participants raised concerns that she can succeed in agriculture science because this field could generate high income, especially through entrepreneurship. For instance, participant 2 asserts that she can generate high income in agriculture science. 
"Participant 2: I do choose nursing as my initial option to further studies but I'm more interested in the agriculture sector. I think agriculture is an income generating career"

Other informant asserts that agriculture science as a platform to her to expanding her knowledge and information on issues regarding this field:

"Participant 1: I want to help others by becoming an extension agent such as agriculture officer who will share knowledge, information and awareness about agriculture with the community" science:

Another pointed out she wants to change the negative perception of others on agriculture

"Participant 3: My parents want to change the perception of our relatives and surrounding community that agriculture is a backward field. Hence, I got the urge and the perseverance to further in agriculture science. I hope my future career is something related to agriculture science".

\section{Discussion}

Generally, parental and family support had an influence on the perseverance of students into agriculture science. Participants advocate that parents should support their children to select the program of their choice. However, as noted by some participants that the negative response by some relatives and close friends has resulted in low persistence of students into agriculture science. Overall, the findings regarding support from the closest individuals are consistent with previous research by (Seemiller \& Grace, 2016; Swan \& De Lay, 2014; Klein \& Washburn, 2012) reported that parents and family influenced persistence of students in agriculture science.

In addition, teacher support such as agriculture teacher, agriculture club advisor and school counselor also served as influencer. This concurred that teacher influences a student's persistence in agriculture science (Ortega-Dela Cruz, 2015). This finding further emphasizes the need for the teacher to diversify their classroom activities. Given these findings, agriculture teachers should be encouraged to structure their teaching and learning activities with additional hand-on and practical activities. Student engagement through various activities and teaching materials can enhance persistence in a particular field due to the different background of the students (Saari \& Rashid, 2013; Omar, Rashid \& Puad, 2018). Other than that, through an individual career counseling and guidance, group career counseling and guidance, counselor teacher helps students to know their own identity, develop potential, and being aware of their interests (Rashid, Bakar, Asimiran \& Tieng, 2009). Mansor and Rashid (2013) mentioned that students need to feel be empowered to construct and manage their own future career, learning and well-being. Furthermore, finding from Saari and Rashid (2013), stated institutions that gave students with better learning environment and experiences have impact on student knowledge, skills and attitude.

The findings indicated that several event or experiences such as family background and growing up environment has most influenced students' persistence in agriculture science. Previous research by Foreman, Retallick and Smalley (2018) found that family background and growing up environment influence an individual's view of something In particular, these events and experiences mentioned by the students were more closely related to the environment condition. Students who exposed to agriculture from early childhood such as family owned farms or private farms and living in the farm or ranch had the potential to continue their studies in agriculture (Klein \& Washburn, 2012). Moreover, students gained early exposure to agriculture fields through his/her growing up environment.

Also, this study found that in terms of individual factors, the students were influenced by own interest and personal targets such as career preferences, high income generation through participation in agriculture and desire to change negative perception towards agriculture field has persists their persistence in agriculture. These finding related to student interest is in line with 
previous studies (Ortega-Dela Cruz, 2015) that individual interest has often been found to match the persistence with the field of agriculture. Interest factor leads students to pursue their studies in the preferred field (Seemiller \& Grace, 2016).

\section{Conclusion}

In conclusion, the factors influencing the persistence of students in agriculture science are support from close individual, school environment, exposure to agriculture and personal factor. These findings will aid in developing a better understanding of student persistence in agriculture science. In addition, this study expands on extant persistence literature by aggregating factors that have been shown to be related to student's persistence. Overall, the findings suggest that further investigation of unseen factors related to the student's persistence in agriculture science needs to be undertaken.

\section{Acknowledgement}

Thank you to the Research Management Center, Universiti Putra Malaysia for the opportunity, support and funding this research. (Project Code: GP IBT/2013/9425000500)

\section{References}

Bennell, P. (2010). Inventing in the future: Creating opportunities for young rural people. Rome: International Fund for Agriculture Development.

Baker, L. M., Chiarelli, C. \& Irani, T., (2013). Recruiting strategically: Increasing enrollment in academic program and literature. Journal of Educational Agricultural Education, 54(3), 54-66.

Barkley, A. P., \& Parrish, D. M. (2005, July). The selection of a major field of study in the College of Agriculture at Kansas State University. American Agricultural Economics Association Annual Meeting. Paper presented at 2005 American Agricultural Economics Association Annual Meeting. Providence, Rhode Island.

Beggs, J. M., Bantham, J. H., \& Taylor, S. (2008). Distinguishing the factors influencing college students' choice of major, College Student Journal, 42(2), 381-394.

Creswell, J. W. (2018). Education research: Planning, conducting, and evaluating quantitative and qualitative research (6th Ed.). Upper Saddle River: Pearson.

Douglas, K., Singh, A.S., \& Zvenyika, K. R. (2017). Perceptions of Swaziland's youth towards farming: A case of Manzini Region. Forestry Research and Engineering: International Journal, 1(3), 83-89.

Esters, L. T., \& Bowen, B. E. (2005) Factors influencing career choices of urban agricultural education students, Journal of Agricultural Education, 46(2), 24-35.

Elder, A. C. (2020). Holistic factors related to student persistence at a large, public university. Journal of Further and Higher Education, 1-14. Doi:10.1080/0309877x.2020.1722802

Foreman, E., Retallick, M., \& Smalley, S. (2018). Changing demographics in college of agriculture and life sciences students. North American Colleges and Teachers of Agriculture Journal, 62(2), 161-167.

Gary, J. W., Stacy A, G., \& Layle, D, L. (1999). Student Perception of Aquaculture Education in the Northeast Region, Journal of Agricultural Education, 40(1), 14-22.

Garwe, E. C. (2015). Trends in student enrolments in agricultural degree programmes in Zimbabwe, Global Journal of Educational Studies, 1(1), 1-16.

Klein, S., \& Washburn, S. (2012). A case study of the search phase of college choice as experienced prospective students visiting a Midwest college agriculture. North American Colleges and Teachers of Agriculture Journal, 56(4), 63-70.

Mansor, M., \& Rashid, A. M. (2013). Career Indecision: A Cross-Sectional Survey among Students of National Youth Skills Training Institutes, Middle-East Journal of Scientific Research, 17(8), 1073-1079.

Nyoni, T., (2012). Current and emerging youth policies and initiatives with a special focus on a link to agriculture. Zimbabwe: Zimbabwe Case Study Draft Report.

Ogbeide, O. A., Ele, I., \& Ikheloa, E., (2015). Young People and Agricultural Employment: Locality and Interest Factors, Mayfair Journal of Agriculture Development in Emerging Economies, 1(1), 1-13. 
Omar, M. K., Rashid, A. M., \& Puad, M. H. M. (2018). Examining job satisfaction factors toward retaining Malaysian TVET instructors in the teaching profession. International Journal of Engineering $\mathcal{E}$ Technology, $7(2.10), 44-49$.

Powell, A.M. (2019). Factors influencing choice of major in the College of Agriculture and Life Sciences at Iowa State University (Doctoral dissertation). Retrieved from https://lib.dr.iastate.edu/etd/17075

Pritchard, A., Fudge, J., Crawford, E., \& Jackson, J. (2018). Undergraduate choice of major and major satisfaction: An expanded role for personality measures. Journal of Marketing for Higher Education, 1-20. Doi:10.108o/o8841241.2018.1442381

Rashid, A. M., Bakar, A. R., Asimiran, S., Tieng, L, P., (2009) Career Development Interventions in Secondary Schools in the State of Terengganu, Malaysia. European Journal of Social Sciences, 8(1), 62-67

Ortega-Dela Cruz, A. O. D. C., (2015). Persistence and retention towards degree completion of BS agriculture students in selected State Universities in Region IV-A, Philippines. African Journal of Agricultural Research, $10(13), 1543-1556$

Ortega-Dela Cruz, A. O. D. C., (2016). A Qualitative Study On The Persistence Of Agro-Fisheries Students Towards Degree Completion, Academic Research International, 7(3), 254-263

Saari, H. A., \& Rashid, A. M. (2013). Relationship between implementation of cooperative vocational education and job offering among apprentice of national dual training system in Malaysia. Middle East Journal of Scientific Research, 18(11), 1578-1583.

Seemiller, C., \& Grace, M. (2016). Generation Z goes to college. San Francisco, CA: JosseyBass

Swan, B., \& De Lay, A. (2014). Agricultural experiences and factors of undergraduates who enroll in a college of agriculture. North American Colleges and Teachers of Agriculture Journal,58(4).

Sumberg, J., Yeboah, T., Flynn, J., \& Anyidoho, N. A. (2017). Young people's perspectives on farming in Ghana: A qualitative study. Food Security, 9(1), 151-161. Doi:10.1007/s12571-016-0646-y

Wildman, M., \& Torres, R. M., (2001) Factors identified when selecting a major in agriculture. Journal of Agriculture Education, 42(2), 46-55. 